\title{
Synthesis and Characterization of Functional Composite Carbon-Geopolymers for Precast Panel Application
}

\author{
Kharisma Noor Afifah ${ }^{1,2,}$, Asrianti Bt.Sunardi ${ }^{1,2}$, Resky Irfanita $^{1,2}$, and SUBAER ${ }^{1,2}$ \\ ${ }^{1}$ Laboratorium Fisika Material, JurusanFisika, UniversitasNegeri Makassar, Indonesia \\ J1. Daeng Tata Raya, Makassar, Indonesia \\ ${ }^{2}$ Konsorsium Riset Geopolimer Indonesia (KORIGI) Laboratorium Beton dan Bahan Bangunan \\ Kampus ITS Sukolilo Surabaya, Indonesia, 6011
}

\begin{abstract}
The purpose of this study is to examine the influence of carbon (C) particles as filler (aggregate) in the production of geopolymers functional composite for possible precast panel application. Geopolymers was synthesized through alkali activation of metakaolin added with carbon particles relative to the mass of metakaolin. The mixture was cured at $70^{\circ} \mathrm{C}$ for 2 hours and the resulting composites were stored in open air for 28 days. The bulk density and the apparent porosity of the composites were measured by using Archimedes method. The thermal properties of the samples was examined by using thermal conductivity measurement and differential scanning calorimetry (DSC). The microstructure characterization of the samples were performed by using $\mathrm{x}$-ray diffraction (XRD) and Scanning Electron Microscopy-Energy Dispersive Spectroscopy (SEM-EDS).
\end{abstract}

\section{Introduction}

Geopolymer is a new type of inorganic polymers synthesized through alkali activated Aluminosilicate materials at temperature below $100^{\circ} \mathrm{C}$ [1]. This new inorganic material consists of polymeric chains of $-\mathrm{Si}-\mathrm{O}-\mathrm{Al}-$ similar to zeolite but its network is amorphous $[2,3]$. Geopolymers is well known for its high early strength, low shrinkage, acid, corrosion, and fire resistance $[3,4]$. Nowadays, geopolymers can be synthesized from kaolin, clays, fly ash, red mud and other aluminosilicate materials [1].

This study utilized metakaolin as a raw material to produce geopolymers paste. Metakaolin is dehydroxilated product of kaolinite mineral at temperature around $750^{\circ} \mathrm{C}$ $[2,5]$. Geopolymers produced from metakaolin has already applied in many areas due to its excellent physical and mechanical properties [8]. Similarly, geopolymers synthesized from

\footnotetext{
* Corresponding author: Knoorafifah@gmail.com
} 
fly ash has also been applied as green concrete in many areas such as precast floor panels, airport runways, and pedestrians paths $[4,5,9,12]$.

Functional composite is a material comprising two or more different starting materials, engineered to gain high performance material [1]. In this study, geopolymers were synthesized by adding carbon (C) particles as aggregate. The use of carbon fiber and particulates as filler (aggregate) of geopolymers have studied intensively in recent years. The addition of carbon fibers or particulates was found to improve the compressive, flexural, and tensile strength as well as heat resistance of geopolymers. The effectivity of carbon fibers and carbon nanoparticles with geopolymers matrices were studied at $750^{\circ} \mathrm{C}$ and revealed that the carbon fibers or nanoparticles did not react with geopolymers constituents $[8,10,11]$.

\section{Experimental method}

Geopolymers paste were synthesized through alkali activation of metakaolin. The composition of the starting materials were adjusted to achieved the molar ratio of $\mathrm{SiO}_{2} / \mathrm{Al}_{2} \mathrm{O}_{3}=3.0, \mathrm{Na}_{2} \mathrm{O} / \mathrm{SiO}_{2}=0.25$, and $\mathrm{H}_{2} \mathrm{O} / \mathrm{Na}_{2} \mathrm{O}=10$. Carbon particles were produced by burning coconut shell, grounded and shieved 200 mesh. The quality of carbon was examined by x-ray diffraction. The mass of carbon particles was varied from $1.0 \%, 1.5 \%$, and $2.5 \%$ relative to the mass of metakaolin. The mixture between geopolymer paste and carbon particles was stirred manually and poured into plastic mold and cured at $70^{\circ} \mathrm{C}$ for 2 hours. The resulting composites were aged 14 days before conducting any measurements.

The bulk density and porosity of the resulting composites were measured by using Archimedes method. The flexural strength of the composites were measured by using three bending flexural measurement. The thermal properties of the materials were studied by using thermal conductivity measurement and Differential Scanning Calorimetry (DSC). The chemical composition and microstructure characters of the resulting materials were examined by using X-ray Diffraction (XRD) and Scanning Electron Microscopy-Energy Dispersive Spectroscopy (SEM-EDS).

\section{Results and discussion}

Fig. 1 shows diffractogram of metakaolin and carbon particles used this study. Both metakaolin and carbon particles have amorphous structures. Metakaolin contain quartz which is originated form kaolinite mineral. 


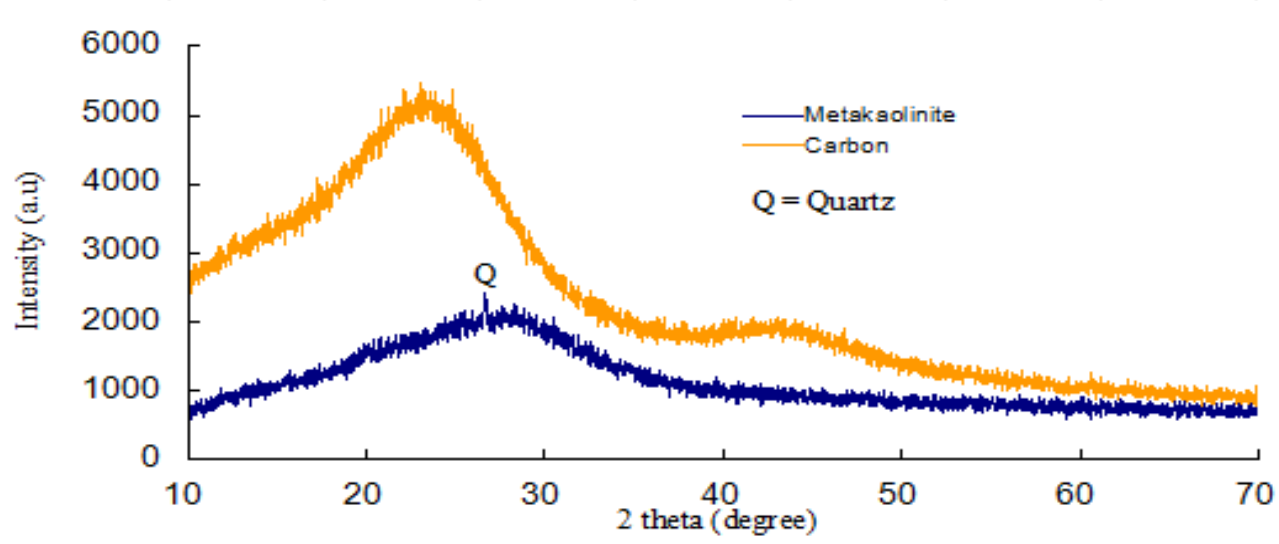

Fig. 1. Diffractogram of metakaolin and carbon particles.

Fig. 2 shows example of carbon-geopolymers composites produced in this study. Sample (a) contain $1.5 \%$ carbon, and sample (b) contain $2.5 \%$ carbon relative to the mass of metakaolin. Scratch on the surface of sample (B) was originated from defect on the surface of mold.

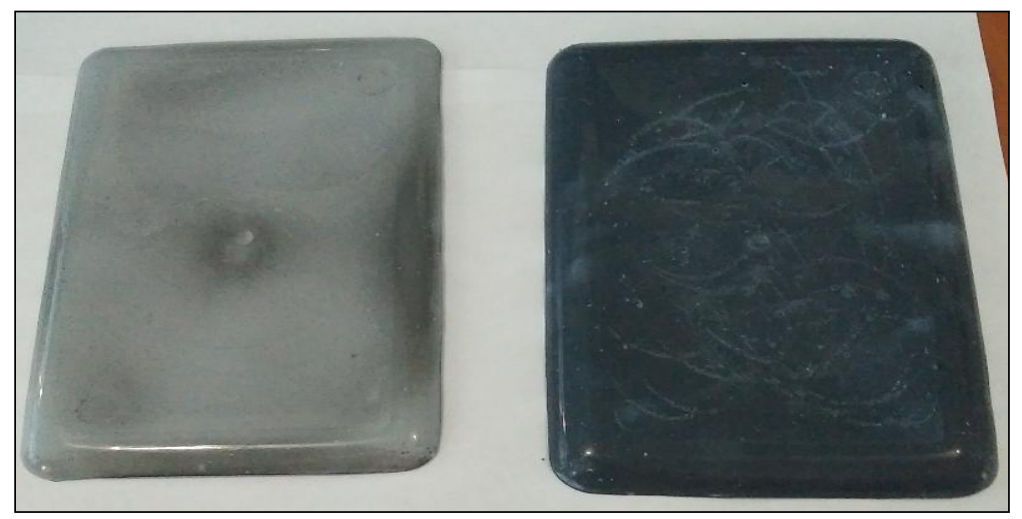

Fig. 2. Carbon-geopolymers composite (a) $1.5 \%$, (b) $2.5 \%$ of carbon relative to the mass of metakaolin.

The maximum mass of of carbon particles added into geopolymers paste was $2.5 \%$ relative to the mass of metakolin. The addition of more carbon into the geopolymers paste keeping constant the concentration of alkali solution will be difficult to mix and results in low strength composite. The bulk density and apparent porosity of the resulting composites were determined by Archimedes method. Table 1 shows the density, the apparent porosity as well as electrical conductivity of the composites. The density and the apparent porosity of the samples revealed that the resulting composites were light and the incorporation of carbon did not increase the volume of pores in the bulk of geopolymers. The thermal and electrical conductivity was measured since carbon is a material with good thermal and electrical properties. The addition of carbon into geopolymers matrices was found to increase the thermal conductivity and it was higher than those made from standard metakaolin geopolymers [4]. 
Table 1. Bulk density, apparent porosity, thermal and electrical conductivity of produced composites.

\begin{tabular}{|c|c|c|c|c|c|}
\hline No. & Sample & $\begin{array}{c}\text { Density } \\
\left(\mathrm{g} / \mathrm{cm}^{3}\right)\end{array}$ & $\begin{array}{c}\text { Apparent Porosity } \\
(\%)\end{array}$ & $\begin{array}{c}\text { Thermal } \\
\text { Conductivity } \\
(\mathrm{W} / \mathrm{mK})\end{array}$ & $\begin{array}{c}\text { Electrical } \\
\text { Conductivity (S/cm) }\end{array}$ \\
\hline 1 & $\begin{array}{c}\text { Geo-C } \\
1.0 \%\end{array}$ & 1.62 & 8.72 & 0.77 & $9.47 \mathrm{E}-07$ \\
\hline 2 & $\begin{array}{c}\text { Geo-C } \\
1.5 \%\end{array}$ & 1.63 & 6.67 & 0.78 & $1.21 \mathrm{E}-06$ \\
\hline 3 & $\begin{array}{c}\text { Geo-C } \\
2.5 \%\end{array}$ & 1.65 & 8.20 & 0.83 & $1.37 \mathrm{E}-06$ \\
\hline
\end{tabular}

The addition of carbon was found to increase the electrical conductivity of the composites but their magnitudes were still in the range of insulator materials [7].

Fig. 3 shows the DSC results of the composites. The measurement was conducted at temperature range $30-400^{\circ} \mathrm{C}$ with a heating rate of $20^{\circ} \mathrm{C} /$ minutes. The addition of carbon particles reduced the heat flow and the enthalpy of the composites. The enthalpy of composite contain $1.0 \%$ carbon was $315.5406 \mathrm{~J} / \mathrm{g}, 278.2725 \mathrm{~J} / \mathrm{g}$ for $2 \%$, and $259.851 \mathrm{~J} / \mathrm{g}$ for $2.5 \%$ carbon. This results are in good agreement with thermal conductivity measurements which showed that the addition of carbon increased the thermal conductivity of the composites.

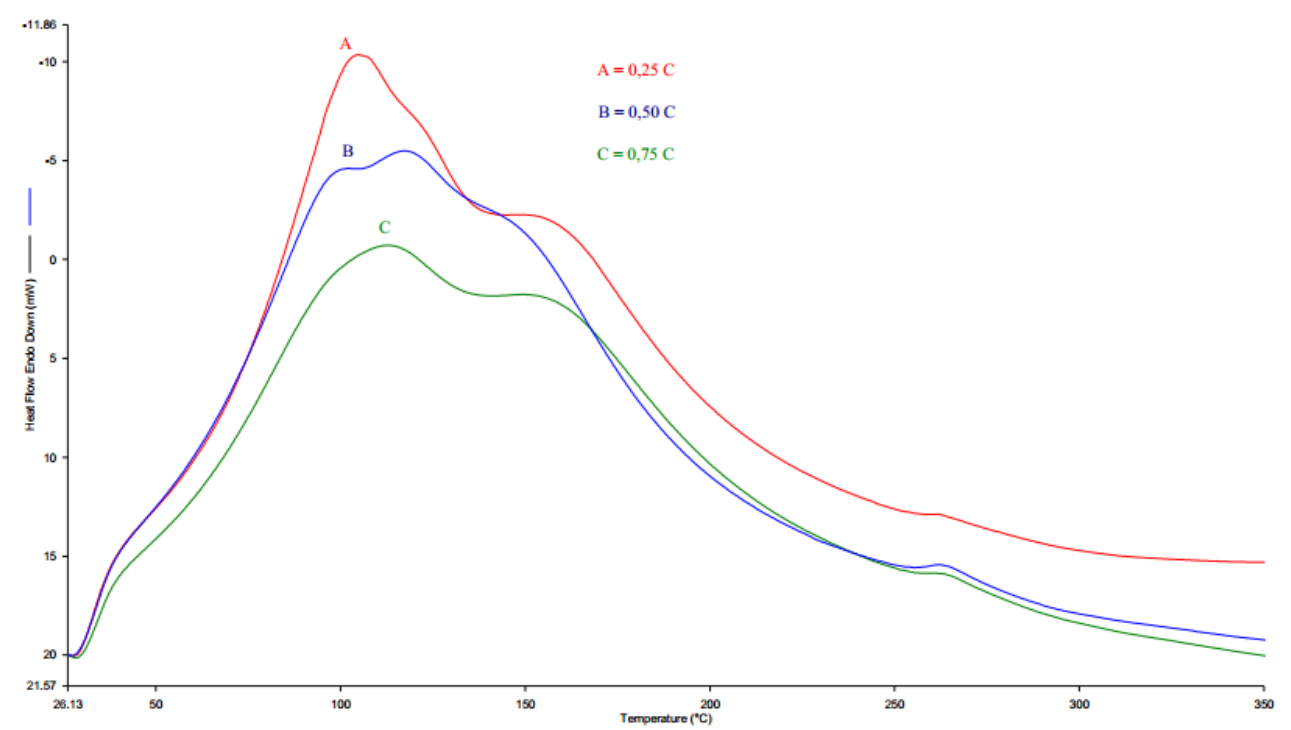

Fig. 3. DSC results of carbon-geopolymer composites with different concentration of carbon.

Diffractogram patterns of the resulting composites is shown in Fig. 4 which showed typical amorphous structure of geopolymers made from metakaolin. The reaction between alkali solution with aluminisilicate species in geopolymers formed a phase of sodium dialuminum phyllo-decaoxodihdroxoalumotrisilicate, $\mathrm{NaAl}_{2}\left(\mathrm{AlSi}_{3}\right) \mathrm{O}_{11}$, The addition of 
carbon was found did not affect the amorphous structure of geopolymers and a small hump observed between $40-45^{\circ} 2 \theta$ was due to the amorphous structure of carbon.

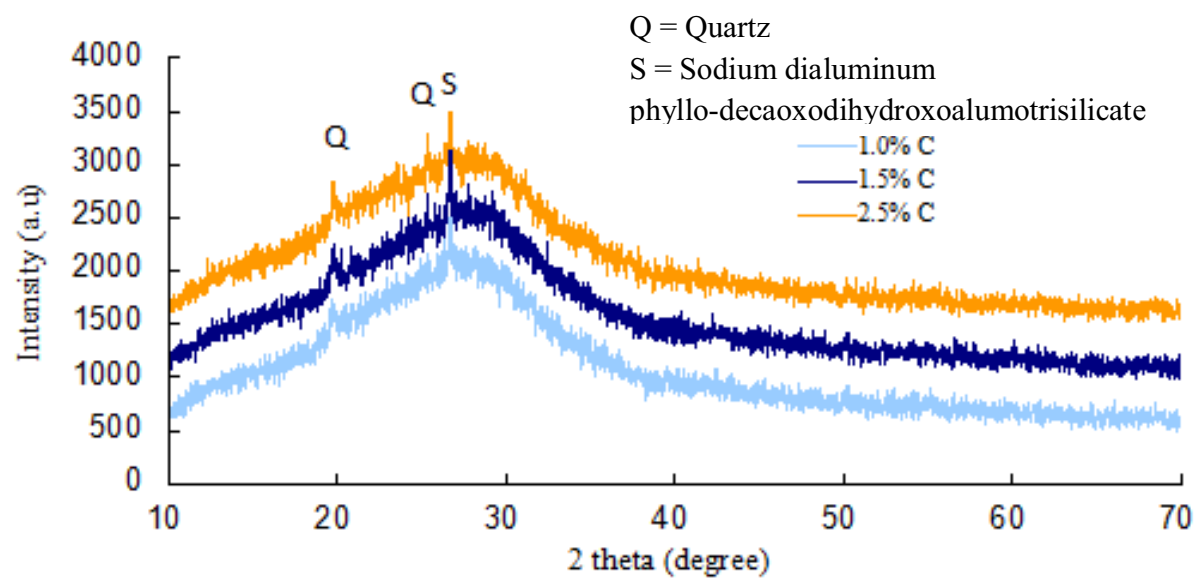

Fig. 4. Diffractogram patterns of carbon-geopolymer composites.

The resulting composites were calcined at $750^{\circ} \mathrm{C}$ to examine the formation of new phases due to high temperature and reaction between carbon particles with other constituent of geopolymers. Fig. 5 shows diffractogram of calcined composites in which the peaks of amorphous structure of geopolymers shifted to lower $2 \theta$ indicating restructure of geopolymers network [4]. Besides that, calcination at $750^{\circ} \mathrm{C}$ caused the loss of $\mathrm{NaAl}_{2}\left(\left(\mathrm{AlSi}_{3}\right) \mathrm{O}_{11}\right.$ phase from the network of geopolymers.

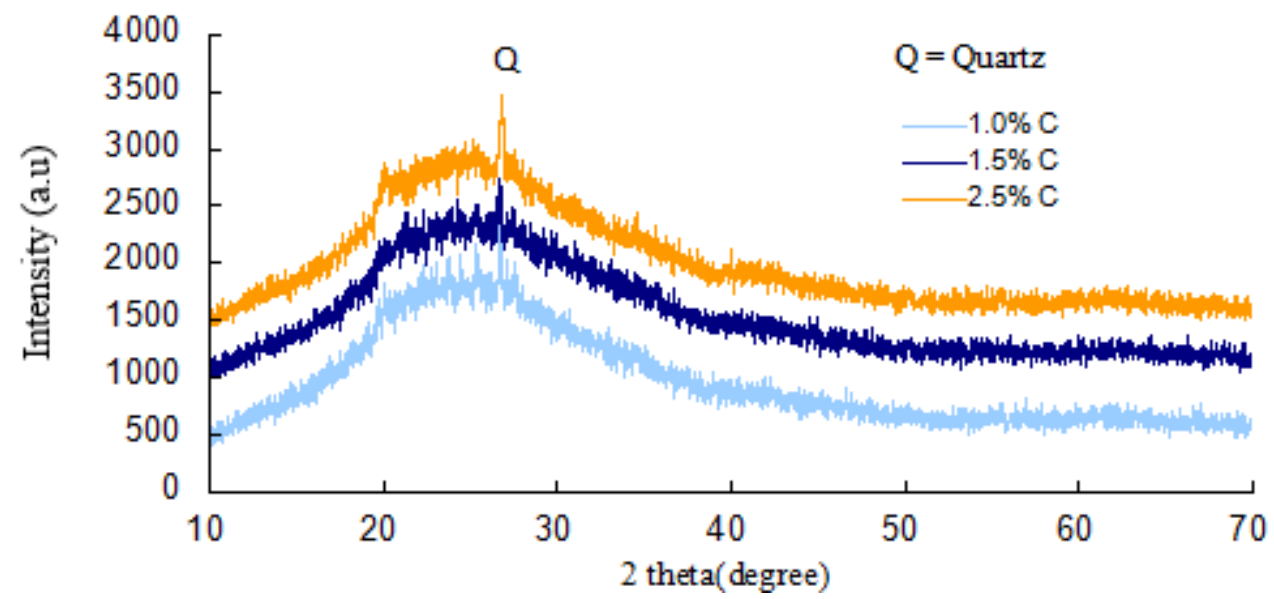

Fig. 5. Diffractogram of calcined carbon-geopolymer composites

Fig. 6 shows SEM images of the surface of the samples. The images showing the interface between carbon particles and geopolymers matrices. The bond between carbon and geopolymers matrix become weaker as the concentration of carbon increase as can be seen in Fig. 6C which shows the propagation of cracks around the interfacial zone between carbon particle and the matrix. Figure $6 \mathrm{~A}$ and $6 \mathrm{~B}$ showed that the bond between carbon particle and the matrix is strong and there is no sign of cracks development. This suggest that the addition 
of excess carbon into the geopolymers matrix will affect the strength of the resulting composites.
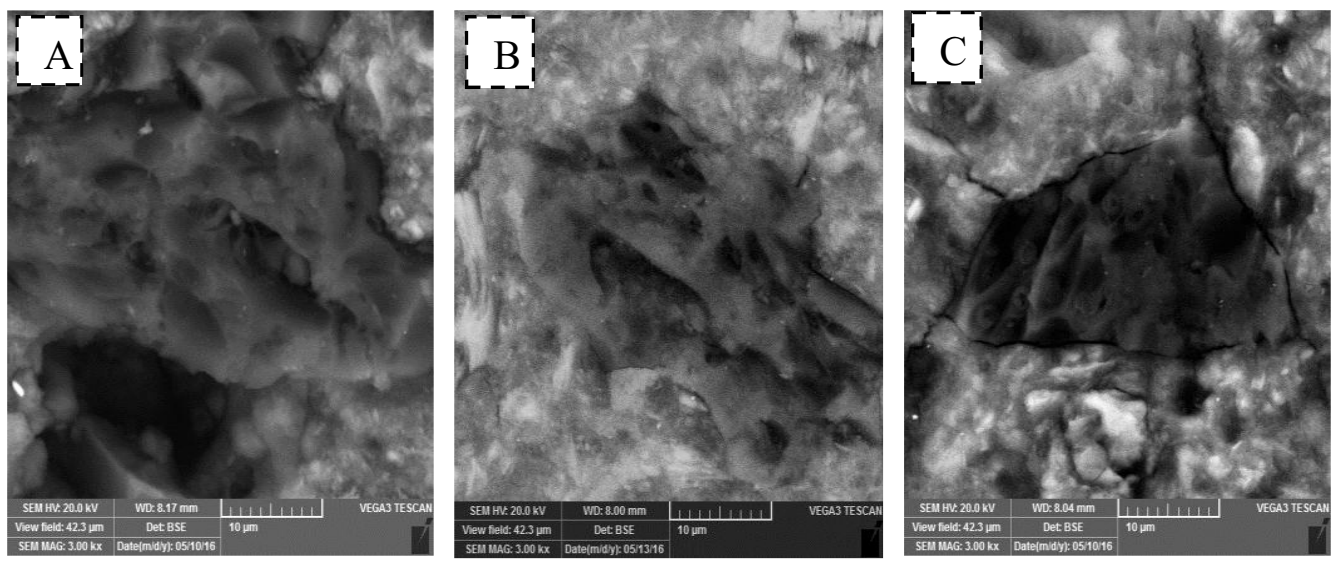

Fig. 6. SEM images of carbon-geopolymer composites contain (a) $1.0 \%$ (b) $1.5 \%$ (c) $2.5 \%$ of carbon particles.

\section{Conclusion}

The synthesis and characterizations of functional composite carbon-geopolymers have been conducted. The geopolymers matrix was synthesized through alkali activation of metakaolin and carbon was derived from burning coconut shell. The resulting composites reveal good surface quality, amorphous structure and good thermal and electrical conductivity for precast panel application. The maximum content of carbon which result in good quality of composite was $1.5 \%$. SEM investigation showed that the bond between carbon and the matrix for samples containing $1 \%$ and $1.5 \%$ of carbon was strong and did not show any cracks opening.

\section{References}

1. J. Davidovits, Geopolimer Poly(sialat)/Poly(sialat-siloxo) Mineral Matrices for Composite Minerals, in ICCM VI \& ECCM 2, Elsevier Applied Science, London, 1 (1987)

2. A. Shvarzman, The Effect of Dehydroxylation/Amorphization Degree on Pozzolanic Activity of Kaolinite, Cement Concrete Res., 33 (2002)

3. J.G.S. Van Jaarsveld, J.S.J. van Deventer, Part I. Theory and Applications, Miner. Eng., $10(1996)$

4. Subaer, Pengantar Fisika Geopolimer, Direktorat Jenderal Pendidikan Tinggi (2012)

5. M.A. Soleimani, R. Naghizadeh, A.R. Mirhabibi, F. Golestanifad, Iranian Journal of Materials Science \& Engineering, 9 (2012)

6. M.L. Granizo, M.T. Blanco-Valera, A. Palomo, J. Mater. Sci., 35 (2000)

7. P. Duxson, A. Fernandez-Gimenez, L. Provis, G.C. Lukey, A. Palomo, J.S.J Van Deventer, J. Mater. Sci., 42 (2007)

8. R. Bligh, T. Glasby, Development of geopolymer precast floor for the global change institute at university of Queensland, www.asec2014.org (2013) 
9. P. Garces, L.G. Andion, G. Gatala, Characterization of Porland Cement Concrete with Carbon Material Admixture, American Concrete Institute, 234 (2006)

10. A.K.M.S. Rahman, NanoFiber Reinforcement of a geopolymer matrix for improved composite materials mechanical performance, Colorado State University. Dissertation (2015)

11. Jorena, Menentukan Energi Gap Semikonduktor Silikon Melalui Pengukuran Resistansi Bahan pada Suhu Beragam, Universitas Sriwijaya (2009)

12. K. P. Puji, O. Tri, N. Lutfiyati, P. Gontjang, Uji Konduktivitas Listrik pada $\mathrm{CaCO} 3$ dan arang kayu dengan metode Four Point Probe, Fisika Laboratorium, Lab.Material (2015) 